ISSN 0258-7122

Bangladesh J. Agril. Res. 40(3): 363-379, September 2015

\title{
FACTORS AFFECTING THE ADOPTION OF IMPROVED VARIETIES OF MUSTARD CULTIVATION IN SOME SELECTED SITES OF BANGLADESH
}

\author{
M. A. MONAYEM MiaH ${ }^{1}$, SADIA AFROZ ${ }^{2}$ \\ M. A. RASHID ${ }^{3}$ AND S. A. M. SHIBLEE ${ }^{4}$
}

\begin{abstract}
Mustard is a leading oil crop in Bangladesh. Relevant data and information on the adoption of improved mustard varieties is very scanty and sporadic in Bangladesh. Therefore, an attempt was made to assess the extent of adoption of improved mustard varieties and their management practices at farm level. The study used data from 540 mustard growing farmers under Manikgonj, Rajshahi and Dinajpur districts. Probit regression model along with other descriptive statistics were used to analyze the collected data. Analysis revealed that the farm level adoption of different production practices were not encouraging as most farmers did not follow the recommendations made by Bangladesh Agricultural Research Institute (BARI) for mustard cultivation. The variety adoption scenario was also discouraging since only $40 \%$ of the farmers cultivated improved mustard varieties. However, farmers showed positive attitude towards adoption of improved mustard varieties since about $53 \%$ of the adopters wanted to increase area under improve mustard cultivation in next growing season considering the high yielding ability, low cultivation cost, high profit, and less labour requirements. Although mustard is considered to be a profitable crop, many farmers showed negative attitude towards its production due to some drawbacks. Non-availability of improved mustard seed was also found to be a barrier to its adoption at farm level.
\end{abstract}

Keywords: Improved mustard, variety adoption, farmers' attitude, production practices.

\section{Introduction}

Rapeseed and mustard are popularly called 'Mustard' which is a leading oilseed crop, covering about $80 \%$ of the total oilseed area and contributing to more than $60 \%$ of the total oilseed production in Bangladesh. It is a cold loving crop which is grown during Rabi season.

The total area and production of mustard is 276.11 thousand hectare and 262.00 thousand tons (Fig 1). The present mustard yield ( $0.95 \mathrm{t} / \mathrm{ha})$ is very low as compared

${ }^{1}$ Senior Scientific Officer, ${ }^{3 \& 4}$ Principal Scientific Officer. Agricultural Economics Division, Bangladesh Agricultural Research Institute (BARI), Joydebpur, Gazipur-1701, ${ }^{2}$ Assistant Chief, Ministry of Planning, Sher-e-Bangla Nagar, Dhaka-1207, Bangladesh. 
to other oilseeds growing countries in the world. The main reasons of lower yield are lack of good quality seed and inadequate adoption of improved production technologies developed by different research institutes (Miah et al., 2014).

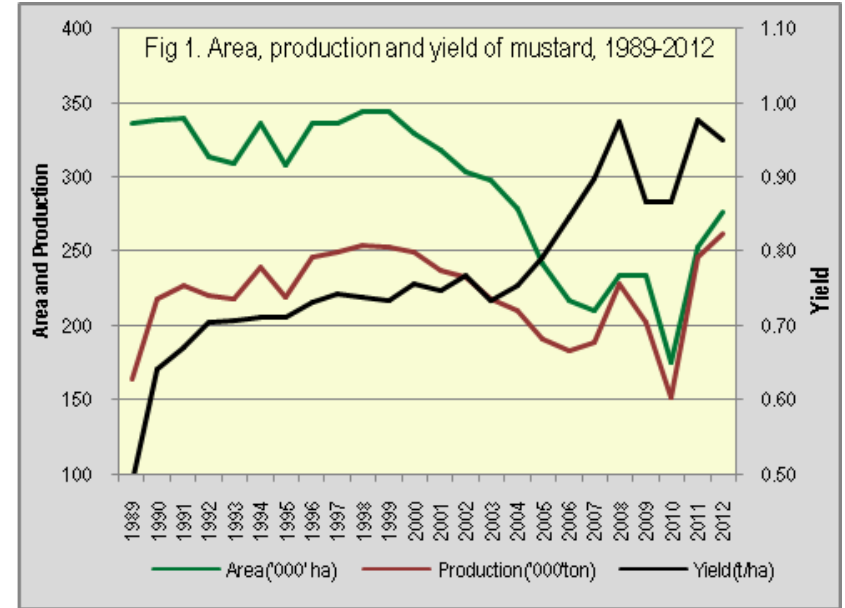

Source: Using data from various issues of BBS

Bangladesh is moving towards self-sufficiency for different agricultural commodities, such as rice, wheat and potato with the higher level of adoption of modern technologies generated by different research institutes. The country is producing about 0.36 million tons of edible oil per year as against the total requirement ${ }^{*}$ of 1.4 million tons (Mallik, 2013). There has been a big gap between supply and demand of edible oils, which has been met through imports incurring a huge amount of foreign exchange (Bangladesh Bank, 2012) every year. In view of the importance of crops, due attention has been given to increase oilseeds production for reducing the huge shortage of cooking oil in the country. Research institutes (mainly BARI) developed a number of improved varieties of mustard and disseminated those for farm level cultivation. But many farmers have not adopted these technologies at all for various reasons which need to be identified. However, the area under improved mustard varieties is gradually increasing and the area under Tori-7 is decreasing year after year (Table 1).

Relevant information on the adoption of improved mustard varieties is very scanty and sporadic in Bangladesh. (Akter et al., 2010) assessed the adoption status of BARI released mustard varieties and evaluated the impact of blocks demonstration on adoption using limited number of samples from Pabna, Tangail and Jamalpur district. Miah and Alam (2008) conducted another study to assess the extent of technology adoption, relative profitability and farmer's attitude toward BARI mustard cultivation. (Anwarul et al., 2007) estimated the status of

\footnotetext{
${ }^{*}$ Total requirement $=22 \mathrm{~g} / \mathrm{cap}$ ita/day x 153 million people
} 
resource allocation in mustard production and measured the technical efficiency of the mustard farmers at Jamalpur district. Fariduzzaman (1996) compared the financial benefits of improved mustard varieties cultivation under improved and traditional management in some areas of Bangladesh.

Table 1. Area under different mustard varieties at national level (61 districts).

\begin{tabular}{l|r|c|r|r|r|c}
\hline \multirow{2}{*}{ Variety } & \multicolumn{2}{|c|}{$2010-2011$} & \multicolumn{2}{c|}{$2009-2010$} & \multicolumn{2}{c}{$2008-2009$} \\
\cline { 2 - 7 } & Area (ha) & $\%$ & Area (ha) & $\%$ & Area (ha) & $\%$ \\
\hline A. Improved & $\mathbf{1 , 3 0 , 4 4 5}$ & $\mathbf{3 0 . 0}$ & $\mathbf{1 , 1 5 , 0 4 1}$ & $\mathbf{2 9 . 4}$ & $\mathbf{1 , 0 0 , 5 8 2}$ & $\mathbf{2 3 . 9}$ \\
BINA Mustard (3-6) & 4,807 & 1.1 & 4,853 & 1.2 & 1,944 & 0.5 \\
BARI Mustard (2-13) & $1,02,572$ & 23.6 & 96,961 & 24.8 & 90,041 & 21.4 \\
BARI Mustard 14 & 13,390 & 3.1 & 7,418 & 1.9 & 5,457 & 1.3 \\
BARI Mustard 15 & 9,666 & 2.2 & 5,104 & 1.3 & 3,135 & 0.7 \\
BARI Mustard 16 & 10 & 0.0 & 705 & 0.2 & 5 & 0.0 \\
B. BARI old variety & $\mathbf{2 , 8 5 , 4 3 7}$ & $\mathbf{6 5 . 8}$ & $\mathbf{2 , 6 0 , 3 7 9}$ & $\mathbf{6 6 . 5}$ & $\mathbf{3 , 0 0 , 6 2 0}$ & $\mathbf{7 1 . 6}$ \\
Tori-7 (Improved) & $2,85,437$ & 65.8 & $2,60,379$ & 66.5 & $3,00,620$ & 71.6 \\
C. Local & $\mathbf{1 8 , 0 1 7}$ & $\mathbf{4 . 2}$ & $\mathbf{1 5 , 9 5 7}$ & $\mathbf{4 . 1}$ & $\mathbf{1 8 , 8 0 3}$ & $\mathbf{4 . 5}$ \\
All variety & $4,33,899$ & 100 & $3,91,377$ & 100 & $4,20,005$ & 100 \\
\hline
\end{tabular}

Source: Estimated using data from district level DAE Offices, 2012.

However, farm level adoption of improved mustard technologies is very much important since it is expected that farmers will benefit through receiving higher yield and income, utilizing vast current fallow land between T. Aman and Boro rice and save a lot of foreign currency through less importation. The policy makers and researchers will also be benefited through the findings of this study. Therefore, the present study was undertaken with the following objectives;

a) To study the adoption status of improved varieties of mustard and its recommended production practices at farm level;

b) To find out the factors associated with adoption of improved varieties of mustard at farm level;

c) To know farmers' experience with and attitudes towards improved mustard cultivation.

\section{Materials and Method}

Study locations and sampling technique: Multi-stages sampling procedure were followed to select sample farmers. In the first stage of sampling, study areas were selected purposively based on the area coverage of mustard during cropping season 2008-2009. Thus, three mustard growing districts, namely Manikgonj, 
Rajshahi, and Dinajpur consisting high (covered $\leq 10 \%$ of total mustard area), medium ( $\leq 5$ to $>10 \%$ area), and low ( $>5 \%$ area) mustard growing areas were selected for the study. In the second stage, in all nine Upazilas under three selected districts were purposively selected taking three Upazila from each district. Before selecting Upazilas, data on the area and production of mustard were collected from Upazila DAE offices and the highest three mustard growing Upazilas were selected for the study. Thirdly, three agricultural blocks were also purposively selected in consultation with Agricultural Officer of the respective Upazila. Finally, a total of 540 mustard growing households (3 districts $\times$ 3 Upazilas $\times 3$ Blocks $\times 20 \mathrm{HHs}$ ) were randomly selected from a complete list of mustard growing farmers.

Method of data collection and period of study: Data and relevant information were collected through personal interview with sampled farmers using a pretested structured interview schedule. The researchers and trained enumerators collected data and information for this study. Data and information were collected during the period from October 2011 to October 2012.

Analytical techniques: For assessing the level of adoption of crop management technologies, respondent farmers were grouped into three categories such as high, medium, and low adopter based on the percent of farmers followed recommended practice with respect to each technology. A higher percentage indicates a higher level of adoption, while a lower percentage indicates a lower level of adoption of a technology. Adoption level was categorized as (70-100\%) as high, $(50-69 \%)$ as medium, and $<50 \%$ as low. This category of adoption was followed by different authors (Islam et al., 2013; Salam et al., 2011; Miah et al., 2010; Akter et al., 2010) in the past.

Probit and Logit models have been used extensively by agricultural production and farming systems economists for studying and analyzing farmers' adoption and diffusion of agricultural interventions. In Pakistan, Malik et al., (1991) and Heisey et al., (1990) used Probit model to examine the role of credit in agricultural development and to identify the determinants of adoption of wheat varieties. Traxler and Byerlee (1992) also used this analysis to identify the characteristics of insecticide farmers. In the present study, Probit regression model was used to find out the factors of adoption and non-adoption of improved varieties of mustard. In order to ascertain the probability of adoption of improved mustard varieties, the following empirical Probit model was employed. Since the dependent variable is dichotomous, Ordinary Least Square (OLS) method is not suitable. Therefore, MLE method was followed to run the Probit model using STATA software. The empirical probit model was as follows:

$$
\mathrm{A}_{\mathrm{i}}=\alpha+\beta_{\mathrm{i}} \mathrm{X}_{\mathrm{i}}+\ldots \ldots . .+\mathrm{U}_{\mathrm{i}}
$$


Where,

$\mathrm{A}_{\mathrm{i}}=$ Farmers adopting improved mustard variety (If adopted $=1$; Otherwise $=0), \alpha=$ Intercept, $X_{\mathrm{i}}=$ Explanatory variables, $\beta_{\mathrm{i}}=$ Coefficients of respective variables, and $\mathrm{U}_{\mathrm{i}}=$ Error term

The adoption of improved mustard variety is likely to be influenced by different explanatory variables. The variables are $\mathrm{X}_{1}=$ Farm size (in decimal), $\mathrm{X}_{2}=$ Family labour (in No./ha), $X_{3}=$ Training received on oilseed (in No.), $X_{4}=$ Availability of improved seed (score), $\mathrm{X}_{5}=$ Influence of neighbouring farmers (score), $\mathrm{X}_{6}=$ Influence of SAAO (score), $\mathrm{X}_{7}=$ Cosmopolitness of the farmer (score), and $\mathrm{X}_{8}=$ Extension contact of the farmers (score).

The procedures of measuring qualitative variables included in the model are briefly discussed below.

Influence of neighbouring farmers and SAAO: These variables were measured based on the level of influences of neighbouring farmers and SAAO in adopting improved mustard variety. Zero value was assigned for 'no influence' and 4 for 'strong influence'. Therefore, the possible scores of these variables ranged from 0 to 4 .

Availability of improved seed: The availability of improved mustard seeds was assigned different values ranging from 0 to $4(0=$ not available, $4=$ plenty $)$ and these values were considered as score.

Cosmopolitness: Different values ( 0 for no visit and 3 for frequent visit) were assigned, based on frequency, for different places of visit. The actual score was then calculated by adding all the values. Possible scores ranged from 0 to 9 .

Extension contact: Ten different extension Medias were considered in this study. All these Medias were assigned different values ( 0 for no contact and 4 for regular contact) according to their importance. The actual score was measured by adding all the values. The possible scores for extension contact were ranged from 0 to 40 .

\section{Results and Discussion}

\section{Adoption of mustard varieties in the study locations}

The farm level adoption of mustard varieties mostly depended on the dissemination process of BARI in association with the Department of Agricultural Extension (DAE). So far BARI has developed and disseminated 16 improved rapeseed and mustard varieties to the farmers. Adoption of mustard varieties at household levels has been discussed below. 
Household level adoption revealed that about $40.2 \%$ mustard farmers adopted improved varieties and almost $60 \%$ adopted BARI old variety (Tori-7). The national level data on mustard area also revealed that Tori-7 is the dominant variety across the country which covered $68.15 \%$ mustard area (Table 1 ). Short duration and to some extent tolerant to biotic and abiotic stresses are the main characteristics that make Tori-7 popular to most of the farmers in the study areas. Among improved varieties, BARI Mustard-15 and BARI Mustard-9 were the highly adopted varieties in the study areas, but area covered by these two varieties is very low at national level. However, BAU Sampod, BARI Mustard-9 and BARI Mustard-15 were the highly adopted varieties in Dinajpur, Rajshahi, and Manikgonj district respectively (Table 2).

Table 2. Level of adoption of different mustard varieties in different study locations.

\begin{tabular}{l|c|c|c|c}
\hline \multirow{2}{*}{ Variety } & \multicolumn{4}{|c}{ \% of farmers adopted the variety } \\
\cline { 2 - 5 } & Manikgonj & Rajshahi & Dinajpur & All area \\
\hline A. Improved & $\mathbf{4 0 . 0}$ & $\mathbf{3 0 . 0}$ & $\mathbf{5 0 . 5}$ & $\mathbf{4 0 . 2}$ \\
BARI Mustard-9 & $5.6(10)$ & $16.7(30)$ & $8.3(15)$ & $10.2(55)$ \\
BARI Mustard-14 & $16.1(29)$ & $2.8(5)$ & $1.1(2)$ & $6.7(36)$ \\
BARI Mustard-15 & $17.2(31)$ & $10.6(19)$ & $12.2(22)$ & $13.3(72)$ \\
BARI Mustard-16 & $1.1(2)$ & -- & -- & $0.4(2)$ \\
BAU Sampod & -- & -- & $17.8(32)$ & $5.9(32)$ \\
Indian Mustard & -- & -- & $11.1(20)$ & $3.7(20)$ \\
\hline B. BARI old variety & $\mathbf{6 0 . 0}$ & $\mathbf{7 0 . 0}$ & $\mathbf{4 9 . 5}$ & $\mathbf{5 9 . 8}$ \\
Tori-7 & $60.0(108)$ & $70.0(126)$ & $49.5(89)$ & $59.8(323)$ \\
All varieties & $100(180)$ & $100(180)$ & $100(180)$ & $100(540)$ \\
\hline
\end{tabular}

Note: Figures in the parentheses indicate the number of respondent farmers.

Source: Field survey, 2011-12.

The respondent farmers were found to be very much enthusiastic towards BARI Mustard-14 and 15 due to their short life cycle (80-85 days) and high yielding potentials. But the rate of adoption of these two varieties was not satisfactory in the study areas mainly due to lack of knowledge about these varieties and nonavailability of seed. The same reasons of low adoption of improved rice varieties were also stated in the study conducted by Jabber and Alam (1993). However, the adoption rates of these two varieties may be higher in other mustard growing areas. Experienced farmers and extension personnel opined that the availability of seeds of short duration T. Aman rice (e.g. BINA Dhan-7), BARI Mustard-14, and BARI Mustard-15 could bring revolution in mustard cultivation in Bangladesh. 
Table 3. Percent of adoption of crop management technologies used in mustard cultivation.

\begin{tabular}{|c|c|c|c|c|c|}
\hline Technology & $\begin{array}{c}\text { Manikgonj } \\
(n=180)\end{array}$ & $\begin{array}{l}\text { Rajshahi } \\
(n=180)\end{array}$ & $\begin{array}{l}\text { Dinajpur } \\
(n=180)\end{array}$ & $\begin{array}{l}\text { All area } \\
(n=540)\end{array}$ & $\begin{array}{l}\text { Adoptio } \\
\text { n level }\end{array}$ \\
\hline \multicolumn{6}{|l|}{$\begin{array}{l}\text { Ploughing and laddering } \\
\text { (No.) }\end{array}$} \\
\hline Recommended no. (4-5) & $10.0(18)$ & $3.3(6)$ & $40.6(73)$ & $18.0(97)$ & Low \\
\hline $\begin{array}{l}\text { Below recommendation } \\
(2-3)\end{array}$ & $90.0(162)$ & $96.7(174)$ & $45.0(81)$ & $77.2(417)$ & \\
\hline $\begin{array}{l}\text { Above recommendation } \\
(>5)\end{array}$ & -- & -- & $14.4(26)$ & $4.8(26)$ & \\
\hline \multicolumn{6}{|l|}{ Seed sowing period } \\
\hline \multicolumn{6}{|l|}{ November) } \\
\hline Above recommendation & $1.7(3)$ & $10.0(18)$ & $66.1(119)$ & $25.9(140)$ & \\
\hline \multicolumn{6}{|l|}{ Seed sowing method } \\
\hline Broadcasting & $100.0(180)$ & $100.0(180)$ & $92.8(167)$ & $97.6(527)$ & High \\
\hline Line sowing & -- & - & $7.2(13)$ & $2.4(13)$ & \\
\hline \multicolumn{6}{|l|}{ Seed rate $(\mathrm{kg} / \mathrm{ha})$} \\
\hline Recommended rate (6-7) & $13.3(24)$ & $5.6(10)$ & $10.6(19)$ & $9.8(53)$ & Low \\
\hline $\begin{array}{l}\text { Below } \\
\text { recommendation(1-5.4) }\end{array}$ & $2.8(5)$ & $0.6(1)$ & $8.9(16)$ & $4.1(22)$ & \\
\hline $\begin{array}{l}\text { Above recommendation } \\
(>7)\end{array}$ & $83.9(151)$ & $93.9(169)$ & $80.6(145)$ & $86.1(465)$ & \\
\hline \multicolumn{6}{|l|}{ No. of irrigation } \\
\hline Recommended (2 times) & $36.7(66)$ & -- & $2.8(5)$ & $13.1(71)$ & Low \\
\hline Below recommendation & $30.6(55)$ & $3.3(6)$ & $42.8(77)$ & $25.6(138)$ & \\
\hline Above recommendation & $5.6(10)$ & -- & -- & $1.9(10)$ & \\
\hline \multicolumn{6}{|l|}{ No. of weeding } \\
\hline Recommended (2 times) & -- & -- & -- & -- & Low \\
\hline Below recommendation & $10.6(19)$ & $3.9(7)$ & -- & $4.8(26)$ & \\
\hline Above recommendation & -- & -- & -- & -- & \\
\hline \multicolumn{6}{|l|}{ Pest control } \\
\hline Do not use pesticides & $73.9(133)$ & $75.0(135)$ & $41.1(74)$ & $63.3(342)$ & -- \\
\hline Used pesticides & $26.1(47)$ & $25.0(45)$ & $58.9(106)$ & $36.7(198)$ & \\
\hline
\end{tabular}

Note: Figures in the parentheses indicate number of farmers responded.

*Indicate recommended period; Adoption level: $70-100 \%$ as high; $50-69 \%$ as medium; \& $<50 \%$ as low.

Source: Field survey, 2011-12.

\section{Technology used in mustard cultivation}

Land preparation includes ploughing, laddering and other operations needed to make the soil suitable for sowing seeds. The mustard growing farmers in the 
study areas ploughed their lands using power tiller. The number of plowing and laddering varied from farm to farm and location to location. Only $18 \%$ mustard farmers followed recommended number of ploughing (4-5 times). Most of them (77.2\%) ploughed their lands 2-3 times. Therefore, land preparation secured low level of adoption. The highest percentage of mustard growing farmers $(96.7 \%)$ at Rajshahi district ploughed lands with the below recommendation level (Table 3).

In the case of mustard, the recommended period of seed sowing is mid October to mid November. $74.1 \%$ mustard farmers sown seeds within recommended period and $25 \%$ farmers sown seed within the $1^{\text {st }} \& 2^{\text {nd }}$ week of October. The highest percentages (98\%) of farmers at Manikgonj district followed the recommended period of sowing. The time of seed sowing was highly adopted because farmers found it convenient to sow during the available range of time. Two types of sowing method were followed for mustard production. Most of the farmers (98\%) followed broadcast method for sowing mustard seed. The recommended seed rate for mustard is $6-7 \mathrm{~kg} / \mathrm{ha}$. About $86.1 \%$ farmers used higher amount of seed than the recommendation level (Table 3).

Two times irrigation, one is after 15-20 days of seed emergence and the other one is during flowering stage, is recommended for achieving higher productivity of mustard. Most of the sample farmers of Dinajpur district (72.8\%) were found to irrigate their crop. About $97 \%$ farmers of Manikgonj district did not irrigate their crop because of rainfall initiated in the early stage of production. The majority of mustard farmers under all the study locations did not weed their crop. About $37 \%$ farmers used pesticides to control insects like aphid and cutworm. The highest proportion of $(65 \%)$ farmers in Dinajpur district applied pesticide to control insects (Table 3).

Farmers' responses on the use of manure and fertilizer in Tori-7 and improved mustard cultivation are presented in Tables 4 and 5. The recommended fertilizer doses are different for Tori-7 and improved varied mustard cultivation. The use of manure and fertilizers by sample farmers varied from location to location. Mustard growing farmers often do not follow the recommendations in applying manure and fertilizers. They tended to use manure and fertilizers either in excess or in very small quantities. In the study areas, both adopter and non-adopter of improved mustard growing sample farmers applied different chemical fertilizers such as Urea, TSP, MoP, Gypsum, and Boric acid in lower quantity compared to the recommended doses. Only zinc oxide was applied in excess quantity than the recommended dose. Therefore, the level of overall adoption of chemical fertilizers was low at farm level. Again, about 7\% respondent mustard growing farmers used manure (cowdung) following recommended dose, whereas 37.3$42.1 \%$ sample farmers applied manure lower quantity compared to the recommended level. Therefore, the level of adoption of manure was found to be low at farm level (Table 4 and 5). 
Table 4. Farmers' practice on using manure and fertilizer in improved variety mustard cultivation.

\begin{tabular}{|c|c|c|c|c|c|}
\hline \multirow[b]{2}{*}{ Particular } & \multicolumn{4}{|c|}{$\%$ of farmers used manure and fertilizers } & \multirow{2}{*}{$\begin{array}{l}\text { Adoption } \\
\text { level }\end{array}$} \\
\hline & $\begin{array}{l}\text { Manikgonj } \\
\quad(\mathrm{n}=72)\end{array}$ & $\begin{array}{c}\text { Rajshahi } \\
(\mathrm{n}=54)\end{array}$ & $\begin{array}{c}\text { Dinajpur } \\
(\mathrm{n}=91)\end{array}$ & $\begin{array}{l}\text { All area } \\
(\mathrm{n}=217)\end{array}$ & \\
\hline \multicolumn{6}{|l|}{ Cowdung (ton/ha) } \\
\hline$* 8-10$ ton/ha & $13.2(12)$ & $1.4(1)$ & $3.7(2)$ & $6.9(15)$ & Low \\
\hline Below recommendation & $38.5(35)$ & $16.7(12)$ & $63.0(34)$ & $37.3(81)$ & \\
\hline Above recommendation & $26.4(24)$ & -- & -- & $11.1(24)$ & \\
\hline \multicolumn{6}{|l|}{ Urea $(\mathbf{k g} / \mathbf{h a})$} \\
\hline$* 250-300 \mathrm{~kg} / \mathrm{ha}$ & $7.0(5)$ & -- & $2.1(2)$ & $3.2(7)$ & Low \\
\hline Below recommendation & $86.1(62)$ & $98.1(53)$ & $90.1(82)$ & 91.7(199) & \\
\hline Above recommendation & $7.0(5)$ & $1.8(1)$ & $5.4(5)$ & $5.1(11)$ & \\
\hline \multicolumn{6}{|l|}{ TSP (kg/ha) } \\
\hline *170-180 kg/ha & $4.2(3)$ & -- & $1.1(1)$ & $1.8(4)$ & Low \\
\hline Below recommendation & $41.7(30)$ & $42.6(23)$ & $61.5(56)$ & $50.2(109)$ & \\
\hline Above recommendation & $34.7(25)$ & & $18.7(17)$ & $19.3(42)$ & \\
\hline \multicolumn{6}{|l|}{ MoP (kg/ha) } \\
\hline$* 85-100 \mathrm{~kg} / \mathrm{ha}$ & $5.6(4)$ & $5.5(3)$ & $19.8(18)$ & $11.5(25)$ & Low \\
\hline Below recommendation & $37.5(27)$ & $66.7(36)$ & $40.7(37)$ & $46.5(101)$ & \\
\hline Above recommendation & $12.5(9)$ & $9.3(5)$ & $54.9(50)$ & $29.5(64)$ & \\
\hline \multicolumn{6}{|l|}{ Gypsum (kg/ha) } \\
\hline$* 150-180 \mathrm{~kg} / \mathrm{ha}$ & -- & $5.6(3)$ & $4.3(4)$ & $2.8(6)$ & Low \\
\hline Below recommendation & $33.3(24)$ & $35.2(19)$ & $29.7(27)$ & $32.3(70)$ & \\
\hline Above recommendation & $6.9(5)$ & $3.7(2)$ & $8.8(8)$ & $6.9(15)$ & \\
\hline \multicolumn{6}{|l|}{ Zinc (kg/ha) } \\
\hline$* 5-7 \mathrm{~kg} / \mathrm{ha}$ & $4.2(3)$ & $1.8(1)$ & $1.1(1)$ & $2.3(5)$ & Low \\
\hline Below recommendation & $1.4(1)$ & -- & $5.4(5)$ & $2.8(6)$ & \\
\hline Above recommendation & $5.6(4)$ & $5.6(3)$ & $26.4(24)$ & $14.3(31)$ & \\
\hline \multicolumn{6}{|l|}{ Boron (kg/ha) } \\
\hline *10-15 kg/ha & $5.6(4)$ & $1.8(1)$ & $9.9(9)$ & $6.5(14)$ & Low \\
\hline Below recommendation & $8.3(6)$ & $9.3(5)$ & $16.4(15)$ & $12.0(26)$ & \\
\hline Above recommendation & $1.4(1)$ & $5.6(3)$ & $3.3(3)$ & $3.2(7)$ & \\
\hline
\end{tabular}

Note: Figures in the parentheses indicate number of farmers responded

*Recommended dose; Adoption level: $70-100 \%$ as high; $50-69 \%$ as medium; and <50\% as low.

Source: Field survey, 2011-12. 
Table 5. Percent of non-adopters used manure and fertilizer in mustard cultivation.

\begin{tabular}{|c|c|c|c|c|c|}
\hline Particular & $\begin{array}{l}\text { Manikgonj } \\
(\mathrm{n}=108)\end{array}$ & $\begin{array}{l}\text { Rajshahi } \\
(n=126)\end{array}$ & $\begin{array}{l}\text { Dinajpur } \\
(\mathrm{n}=89)\end{array}$ & $\begin{array}{l}\text { All area } \\
(n=323)\end{array}$ & $\begin{array}{c}\text { Adoption } \\
\text { level }\end{array}$ \\
\hline \multicolumn{6}{|l|}{ Cowdung (ton/ha) } \\
\hline$* 8-10$ ton/ha & $22.5(20)$ & $0.9(1)$ & $0.8(1)$ & $6.8(22)$ & Low \\
\hline Below recommendation & $50.6(45)$ & $9.3(10)$ & $64.3(81)$ & $42.1(136)$ & \\
\hline Above recommendation & $46.1(41)$ & -- & -- & $12.7(41)$ & \\
\hline \multicolumn{6}{|l|}{ Urea $(\mathbf{k g} / \mathrm{ha})$} \\
\hline$* 200-250 \mathrm{~kg} / \mathrm{ha}$ & $39.8(43)$ & $4.0(5)$ & $7.8(7)$ & $17.0(55)$ & Low \\
\hline Below recommendation & $46.3(50)$ & 93.7 (118) & $89.9(80)$ & $76.8(248)$ & \\
\hline Above recommendation & $13.8(15)$ & $1.5(2)$ & $1.1(1)$ & $5.5(18)$ & \\
\hline \multicolumn{6}{|l|}{$\operatorname{TSP}(\mathrm{kg} / \mathrm{ha})$} \\
\hline$* 150-170 \mathrm{~kg} / \mathrm{ha}$ & $7.4(8)$ & $0.7(1)$ & $3.3(3)$ & $3.7(12)$ & Low \\
\hline Below recommendation & $51.6(55)$ & $34.1(43)$ & $78.6(70)$ & $52.0(168)$ & \\
\hline Above recommendation & $23.1(25)$ & $1.6(2)$ & $12.4(11)$ & $11.8(38)$ & \\
\hline \multicolumn{6}{|l|}{ MoP (kg/ha) } \\
\hline$* 70-85 \mathrm{~kg} / \mathrm{ha}$ & $30.6(33)$ & $19.8(25)$ & $12.4(11)$ & $21.4(69)$ & Low \\
\hline Below recommendation & $39.0(42)$ & $44.4(56)$ & $31.5(28)$ & $39.0(126)$ & \\
\hline Above recommendation & $21.3(23)$ & $6.3(8)$ & $46.1(41)$ & $22.3(72)$ & \\
\hline \multicolumn{6}{|l|}{ Gypsum (kg/ha) } \\
\hline$* 120-150 \mathrm{~kg} / \mathrm{ha}$ & $4.6(5)$ & $6.33(8)$ & $1.1(1)$ & $4.3(14)$ & Low \\
\hline Below recommendation & $25.0(27)$ & $2.8(3)$ & $1.1(1)$ & $23.5(76)$ & \\
\hline Above recommendation & $11.1(12)$ & $8.0(10)$ & $2.2(2)$ & $7.4(24)$ & \\
\hline \multicolumn{6}{|l|}{ Zinc (kg/ha) } \\
\hline$* 5-7 \mathrm{~kg} / \mathrm{ha}$ & -- & -- & -- & -- & Low \\
\hline Below recommendation & -- & $0.8(1)$ & $4.5(4)$ & $1.5(5)$ & \\
\hline Above recommendation & $11.1(12)$ & $13.5(17)$ & $27.0(24)$ & $16.4(53)$ & \\
\hline \multicolumn{6}{|l|}{ Boron $(\mathbf{k g} / \mathrm{ha})$} \\
\hline$* 10-15 \mathrm{~kg} / \mathrm{ha}$ & $5.6(6)$ & $3.2(4)$ & $6.7(6)$ & $5.0(16)$ & Low \\
\hline Below recommendation & $5.6(6)$ & $7.1(9)$ & $20.2(18)$ & $10.2(33)$ & \\
\hline Above recommendation & $2.8(3)$ & $3.2(4)$ & $2.2(2)$ & $2.8(9)$ & \\
\hline
\end{tabular}

Note: Figures in the parentheses indicate number of farmers responded

*Recommended dose; Adoption level: $70-100 \%$ as high; 50-69\% as medium; and $<50 \%$ as low.

Source: Field survey, 2011-12. 


\section{Determinants of adoption of improved mustard varieties}

The adoption of improved mustard varieties was likely to be influenced by different socio-economic factors. Data in Table 6 show that farm size, family labor, training on oilseed, influences of neighbor, influences of SAAO, cosmopoliteness, and extension contact had positive and importantly influence on the adoption of improved mustard varieties in the study areas.

Marginal coefficient indicate that if farm size increased by $100 \%$, the probability of adopting improved mustard varieties would increase at $0.017 \%$. Again, if the number of family labor increased by $100 \%$ the probability of adopting improved mustard varieties would increase by $1.01 \%$. The coefficients of seed availability, influences of SAAO, cosmopolitness, and extension contact were positive and significant. If these variables increase by $100 \%$ the probability of adopting improved mustard varieties would increase by $13.26 \%, 14.67 \%, 5.06 \%$, and $1.18 \%$ respectively (Table 7 ).

Table 6. Maximum likelihood estimates of variable determining adoption of improved mustard varieties among respondent farmers.

\begin{tabular}{|c|c|c|c|c|}
\hline Explanatory variable & Coefficient & Standard Error & z-statistic & Probability \\
\hline Constant & $\begin{array}{c}- \\
3.70295 * * *\end{array}$ & 0.413278 & -8.96 & 0.000 \\
\hline Farm size (decimal) & $0.00045^{*}$ & 0.0002515 & 1.80 & 0.072 \\
\hline Family labour (number/ha) & $0.02763 * * *$ & 0.0045008 & 6.14 & 0.000 \\
\hline Training on oilseed (number) & 0.09835 & 0.1206966 & 0.81 & 0.415 \\
\hline $\begin{array}{l}\text { Availability of HYV seed } \\
\text { (score) }\end{array}$ & $0.36302 * * *$ & 0.0902197 & 4.02 & 0.000 \\
\hline $\begin{array}{l}\text { Influences of neighbour } \\
\text { (score) }\end{array}$ & 0.07377 & 0.0740819 & 1.00 & 0.319 \\
\hline Influences of SAAO (score) & $0.40150 * * *$ & 0.0699717 & 5.74 & 0.000 \\
\hline $\begin{array}{l}\text { Farmers' cosmopolitness } \\
\text { (score) }\end{array}$ & $0.13839 * *$ & 0.0607972 & 2.28 & 0.023 \\
\hline Extension contact (score) & $0.03230 * *$ & 0.0150383 & 2.15 & 0.032 \\
\hline
\end{tabular}

Note: Number of observation $=537 ;$ LR chi-square $(8)=321.6 ;$ Log likelihood $=$ 190.47736;

'***' '**' \& '*' represent significant at $1 \%, 5 \%$ and $10 \%$ level respectively

Higher score value represents the higher probability of improved variety adoption

Source: Field survey, 2011-12. 
Table 7. Marginal effect of the variables determining adoption of improved mustard varieties among respondent farmers.

\begin{tabular}{lccccc}
\hline \multicolumn{1}{c|}{ Explanatory variable } & Dy/dx & $\begin{array}{c}\text { Standard } \\
\text { Error }\end{array}$ & z-statistic & Probability \\
\hline Farm size (decimal) & $0.000165 *$ & 0.00009 & 1.80 & 0.071 \\
Family labour (number/ha) & $0.010094 * *$ & 0.00167 & 6.04 & 0.000 \\
Training on oilseed (number) & 0.035930 & 0.04414 & 0.81 & 0.416 \\
Availability of HYV seed (score) & $0.132622^{* * *}$ & 0.03307 & 4.01 & 0.000 \\
Influences of neighbour (score) & 0.026949 & 0.02699 & 1.00 & 0.318 \\
Influences of SAAO (score) & $0.146682 * * *$ & 0.02669 & 5.50 & 0.000 \\
Farmers' cosmopolitness (score) & $0.050557 * *$ & 0.02218 & 2.28 & 0.023 \\
Extension contact (score) & $0.011799 * *$ & 0.00551 & 2.14 & 0.032 \\
\hline
\end{tabular}

Note: '***' ' $* *$ ’ $\&$ '*' represent significant at $1 \%, 5 \%$ and $10 \%$ level respectively

\section{Farmers' attitudes toward mustard cultivation}

The respondent farmers were asked to mention the possibility of devoting more area for improved mustard cultivation. In the case of adopters, almost $52 \%$ of the mustard farmers showed their interest to increase mustard cultivation in the next year. In the case of non-adopters, $46.65 \%$ farmers showed their interest to expand mustard cultivation. About $48 \%$ adopter and 52\% non-adopter indicated that they would not increase mustard area in the next year. Although mustard is a profitable crop, $50.19 \%$ farmers will not increase mustard cultivation in the next year due to various reasons (Table 8).

Table 8. Farmers' perceptions regarding further increase or decrease of area under mustard cultivation in the next year,

\begin{tabular}{ll|c|c|c}
\hline \multirow{2}{*}{ Particulars } & \multicolumn{3}{|c}{ \% of farmers opined } \\
\cline { 3 - 5 } & Adaptor $(n=197)$ & Non-adaptor $(n=343)$ & All category $(n=540)$ \\
\hline 1. Increase & 51.78 & 46.65 & 48.52 \\
2. & Not increase & 47.72 & 51.60 & 50.19 \\
3. & Decrease & 0.51 & 1.75 & 1.30 \\
\hline
\end{tabular}

Source: Field survey, 2011-12

The highest percentage of the sample mustard growing farmers mentioned their willingness to expand their mustard areas for the next year due to higher yield and good price of the produces. They also mentioned various reasons behind their eagerness to increase mustard cultivation in future. The reasons were low cost but high profit, easy cultivation and needs les labour, available lands for mustard cultivation (Table 9). 
Table 9. Farmers' reasons for increasing mustard cultivation in the near future.

\begin{tabular}{l|c}
\hline \multicolumn{1}{c}{ Reasons for devoting more area } & \% of responses $(n=540)$ \\
\hline 1. Higher yield and get good product price & 38.9 \\
2. Low cost but high profit & 34.1 \\
3. Easy cultivation and needs less labour & 14.6 \\
4. Availability of cultivable land & 3.9 \\
5. Others* & 3.1 \\
\hline
\end{tabular}

*Create new cropping pattern, invest mustard income on Boro cultivation, less attack of insects, early soil moisture, and family consumption.

Source: Field survey, 2011-12

Some adopters and non-adopters mustard farmers mentioned various reasons for not expanding their area in the next year. The important reasons were scarcity of cultivable land as they need to grow other crops. A very small percentage of respondent farmers mentioned about higher cost of production which is considered to be a barrier toward expansion of mustard cultivation in the next year. This reason is not significant because most farmers mentioned that mustard cultivation requires lower cost compared to other crops. About $10.2 \%$ farmers mentioned that mustard cultivation is less profitable compared to maize, onion, carrot and vegetables. Some farmers did not want to increase mustard cultivation because it hampers Boro rice cultivation due to lack of short duration improved variety (Table 10). A small number of adopter and non-adopter farmers also mentioned some reasons for decreasing their area for the next year. The reasons were scarcity of suitable cultivable land as they need to grow other crops.

Table 10. Reasons for not increasing oilseed cultivation in the next year.

\begin{tabular}{lc}
\hline \multicolumn{1}{c|}{ Reasons for not increasing } & \% of responses $(n=540)$ \\
\hline 1. Scarcity of cultivable land & 19.6 \\
2. Higher cost of production & 2.6 \\
3. Lack of irrigation facility & 0.9 \\
4. Scarcity of improved short duration seed & 0.9 \\
5. Increase rice cultivation & 2.4 \\
6. Others* & 4.8 \\
\hline
\end{tabular}

*Delay in Boro rice production, lack of short duration variety seed, foggy weather, decrease soil fertility due to use same cropping pattern repeatedly, increase rice cultivation, and lack of irrigation facility.

Source: Field survey, 2011-12. 


\section{Facility needed for increasing mustard cultivation}

Some of the respondent farmers mentioned some facilities that need to be created for them to expand mustard area in the near future. Their demanded needs are displayed in Table 11.

The availability of cultivable land is very much important for growing or expanding area for mustard. About $20.4 \%$ farmers opined in favour of devoting area for mustard cultivation for the next year if they can manage more cultivable land through lease or mortgage. Availability of short duration improved mustard variety is a pre-requisite for expanding mustard cultivation throughout the country. Many farmers also demanded short duration T. Aman rice variety so that they can harvest Aman rice early and cultivate mustard in between T. Aman and Boro rice cultivation.

Good quality seeds, fertilizers and pesticides are important inputs for producing mustard profitably. Therefore, these inputs should be available to the farmers at lower price. A good segment of the sample farmers opined in favour of reducing the input price (Table 11).

Farmers need cash money at the time of cultivation. So, institutional credit facilities should be made available at the right time to the farmers to encourage them in producing more crops. Some mustard farmers wanted easy access to institutional credit facilities with easy terms and conditions since the rate of interest of non-institutional credit is very high.

Irrigation is an important input for crop production. It helps increasing crop productivity to a great extent. Most of the study areas are facilitated with irrigation. But mustard farmers are often constrained by the frequent load shedding of electricity that hampers their crop production practices. Nevertheless, some farmers till do not have adequate irrigation facility. Therefore, they have demanded this facility in the study areas.

Product price is very much important to the mustard farmers for higher production. Some of adopter and non-adopter mustard farmers opined that they could not receive fair prices of their produces.

Training is an important tool that enhances knowledge and skill of the farmers. It is noted that a small percentage of mustard farmers approached for receiving hand-on training on oilseed production. Farmers also proposed some other facilities such as short duration variety of T. Aman rice (BINA Dhan-7); cooperation from extension personnel; crop threshing machine; low cost of plough; removal of water logging problem; and storage facility (Table 11). 
Table 11. Facilities demanded by the sample farmers for increasing oilseed cultivation.

\begin{tabular}{lc}
\hline \multicolumn{1}{c|}{ Facility } & \% of responses $(n=540)$ \\
\hline 1. Availability of more cultivable land & 20.4 \\
2. Need short duration and improved varieties & 17.0 \\
3. Ensuring lower price of inputs (seed, fertilizer, & 12.0 \\
pesticides \& diesel) & 5.7 \\
4. Credit facility with easy term & 2.6 \\
5. Adequate irrigation facility & 5.2 \\
6. Ensuring fair price of the produces & 3.7 \\
7. Hand-on training on oilseed cultivation & 9.4 \\
8. Others*
\end{tabular}

* Short duration variety of T.Aman rice, cooperation from extension personnel, low cost of plough, removal of water logging problem, crop threshing machine, removal of labour scarcity, and storage facility.

Source: Field survey, 2011-12

\section{Conclusion and Recommendation}

The study assessed the level of adoption of improved mustard varieties along with management technologies at farm level and attitudes towards mustard cultivation. The study revealed the low level of adoptions of the improved mustard technologies at farm level. The lion share of the total mustard areas are planted to BARI old mustard variety (Tori-7). The adoption of improved mustard variety was very low. Different socioeconomic factors, such as family labour, availability of improved seed, farmers' cosmopolitness, and extension contact significantly influence farmers to adopt improved mustard varieties. The majority of the respondent farmers wanted to increase the cultivation of improved mustard varieties in the next year due to higher yield, low cultivation cost, higher profit, and less labour requirement.

In order to increase the adoption of improved mustard varieties at farm level, the Government should ensure the adequate supply of improved and short-duration seeds of mustard and T-Aman rice at farm level. Hand-on training on improved mustard cultivation and crop management practices for the mustard growing farmers is also an important factor of adoption and government should take care of it. Existing extension services should be strengthened for higher adoption of mustard technologies. Affordable price of the inputs, fair price of the output, and credit facilities with favourable terms \& conditions influence mustard farmers to a greater extent to adopt improved technology. Therefore, Government should 
take appropriate steps on these aspects so that farmers become enthusiastic toward improved mustard cultivation.

\section{Acknowledgement}

This article has been prepared from the project titled 'Assessment of socioeconomic impacts of oilseed research and development in Bangladesh' funded by National Agricultural Technology Project (NATP: Phase 1), BARC, Farmgate, Dhaka. The authors are highly grateful to BARC for funding this project.

\section{References}

Akter, M., M.A.M. Miah, M.M.H. Khurram, M.S. Rahman and Q.M. Alam. 2010. Economic feasibility of soybean production in some selected areas of Bangladesh. Bangladesh Journal of Agricultural Research, 35(4): 561-571.

Akter, M., M. A. M. Miah, M. S. Rahman and M. M. H. Khurram. 2010. Adoption and relative profitability of groundnut (Arachis hypogaea L.) cultivation in char areas of Bangladesh. Bangladesh J. of agri. 2010, 35(1): 85-95.

Anwarul, M., Q.M. Alam and M.A. Based. 2007. Technical efficiency of mustard production in Jamalpur district. Annual Research Report 2007-08, Oilseed Research Centre, BARI, Joydebpur, Gazipur.

Bakr, M.A. and H.U. Ahmed. 2009. Advances in oilseed research in Bangladesh: Proceeding of the national workshop on 'Research and Development of Oilseed Crops in Bangladesh and Future Challenges', BARI, Gazipur, P. 11.

Bangladesh Bank, 2012. Monthly Economic Trends, December, 2012. Statistics Department, Bangladesh Bank, Head Office, Dhaka, Bangladesh.

BBS, 2012. Agricultural Statistics of Bangladesh. Bangladesh Bureau of Statistics, Ministry of Planning, Government of the People's Republic of Bangladesh, Dhaka.

Fariduzzaman, M. 1996. An economic study of some improved varieties of mustard production under improved managements and farmers management in some selected areas of Bangladesh. Unpublished M.S. Thesis, Department of Agricultural Economics, Bangladesh Agricultural University, Mymensingh.

Heisey, P., W. Tetlay, Z. Ahmad and M. Ahmad. 1990. Varietal change in post-green revolution agriculture: empirical evidence for wheat in Pakistan. Journal of Agricultural Economics. 44(3): 428-442.

Islam, Q. M. S., M.A.M. Miah, M.S. Rahman and M.S. Hossain. 2013. Adoption of BARI mung varieties and its constraints to higher production in southern region of Bangladesh. Bangladesh J. Agricultural Research, 38(1): 85-96.

Jabber, M.A. and M.S. Alam. 1993. Adoption of modern rice varieties in Bangladesh. The Bangladesh Journal of Agricultural Economics, Vol. XVI, No. 2 
Malik, S.J., M. Mushtaq and M.A. Gill. 1991. The role of institutional credit in the agricultural development of Pakistan. The Pakistan Development Review. 30(4): 1039-1048.

Miah, M.A.M. and Q.M. Alam. 2008. Adoption and relative profitability of mustard production in Bangladesh. Annual Research Report 2007-08, Oilseed Research Centre, BARI, Joydebpur, Gazipur.

Miah, M.A.M., M. Akter, M.M.M.H. Khurram, M.A. Salam and M.A. Uddin. 2010. Adoption of BARI mustard technology in selected areas of Bangladesh. Eco-friendly Agriculture Journal, 3(2): 123-130, 2010.

Miah, M.A.M., M.A. Rashid and S.A.M. Shiblee. 2014. Assessment of socioeconomic impacts of oilseed research and development in Bangladesh. Final report submitted to the Agricultural Economics and Rural Sociology, BARC, Farmgate, Dhaka.

Mallik, M.S.A. 2013. Quality seed production of oilseed crops: An overview. Paper presented in the workshop on 'Modern Techniques for Quality Seed Production of Oilseed Crops'. Oilseed Research Centre, Bangladesh Agricultural Research Institute, Gazipur.

Salam, M.A., M.M.H. Khurram, S.M. Moniruzzaman and S. Hossain. 2011. The economics of sesame production in two selected areas of Bangladesh. Bangladesh Journal of Agriculture, 36(1): 117-129.

Traxler, G. and Byerlee, D. 1992. Crop management research and extension: the products and their impact on productivity. CIMMYT Economics Paper No. 5. Mexico, D.F.: CIMMYT. 